\title{
PERANAN GURU PEMBIMBING KHUSUS LULUSAN NON-PENDIDIKAN LUAR BIASA (PLB) TERHADAP PELAYANAN ANAK BERKEBUTUHAN KHUSUS DI SEKOLAH INKLUSI KABUPATEN LUMAJANG
}

\author{
Erika Yunia Wardah \\ Pendidikan Luar Biasa, Pascasarjana, Universitas Negeri Surabaya \\ erikayuniawardah@gmail.com
}

\begin{abstract}
Abstrak
Pendidikan inklusif merupakan pendidikan yang memberikan kesempatan yang sama pada peserta didik baik yang memiliki kelainan mental ataupun fisik untuk belajar bersama dengan teman seusianya di sekolah regular. Pendidikan inklusif memiliki tujuan untuk mengurangi sikap diskriminatif pada anak berkebutuhan khusus. Peranan seorang guru pembimbing khusus sangat diperlukan dalam mengoptimalkan perkembangan anak secara akademik maupun non akademik. Guru pembimbing khusus bukan semata-mata mendampingi anak dalam belajar melainkan juga memberikan pelayanan yang sesuai dengan kebutuhannya. Terselenggaranya sekolah inklusif di kabupaten Lumajang memunculkan suatu isu di masyarakat mengenai kemampuan guru pembimbing khusus dalam memberikan pelayanan bagi anak berkebutuhan khusus yang notabenenya bukanlah dari lulusan Sarjana Pendidikan Luar Biasa. Penelitian ini menggunakan metode deskriptif kualitatif dengan mengungkapkan kejadian secara mendalam dan terfokus pada kejadian yang ditemukan secara alami. Sumber data pada penelitian ini diperoleh dari guru pembimbing khusus, kepala sekolah dan koordinator bagian sekolah inklusif di Dinas Pendidikan Kabupaten Lumajang. Sehingga data yang ditemukan berupa data deskriptif hasil wawancara, observasi dan dokumentasi terkait dengan fokus penelitian.

Melalui metode penelitian kualitatif didapatkan hasil penelitian sebagai berikut: (1) Dalam suatu lingkung sekolah Inklusif Guru Pembimbing Khusus bukanlah lulusan Sarjana Pendidikan Luar Biasa, melainkan lulusan Pendidikan Bahasa Indonesia, Matematika, Olahraga, Sains, PGSD. Mereka adalah guru kelas ataupun guru matapelajaran yang ditunjuk oleh kepala sekolah untuk menjadi Guru Pembimbing Khusus di instansi tersebut. (2) Perencanaan pelayanan bagi anak berkebutuhan khusus masih belum berjalan dengan baik, terutama dalam perencanaan program kekhususan bagi anak berkebutuhan khusus. (3) Pelayanan bagi anak berkebutuhan khusus tidak dapat berjalan dengan efektif dikarenakan minimnya pengetahuan guru pembimbing khusus non-PLB tentang anak berkebutuhan khusus. (4) Dinas Pendidikan Kabupaten Lumajang telah mengupayakan pelatihan untuk guru pembimbing khusus non-PLB tentang program inklusif dan pelayanan bagi anak berkebutuhan khusus.
\end{abstract}

Kata Kunci: Guru Pembimbing Khusus, Sekolah Inklusi, Anak Berkebutuhan Khusus. 


\begin{abstract}
Inclusive education is education that provides equal opportunities for students who have mental or physical disorders to learn together with friends of their age at regular school. Inclusive education aims to reduce discriminatory attitudes towards children with special needs. The role of a special supervisor is very important in optimizing children's development both academically and non-academically. Shadow teachers (GPK) are not merely accompanying children in learning but also providing services that suit their needs. The implementation of inclusive schools in Lumajang district raises an issue in the community regarding the ability of the supervising teacher specifically to provide services for children with special needs who are not graduates of the Bachelor of Special Education. This study uses a qualitative descriptive method by revealing events in depth and focusing on events found naturally. Sources of data in this study were obtained from special supervisors, principals and coordinator inclusion part in Lumajang District Education Office. So that the data found is in the form of descriptive data from interviews, observations and documentation related to the focus of the study.

Through qualitative research methods the results of the study are as follows: (1) In an Inclusive school environment shadow teacher (GPK) are not graduates of Special Education, but graduates of Indonesian Language Education, Mathematics, Sports, Science, PGSD. They are class teachers or subject teachers who are appointed by the principal to become a Special Tutor Teacher in the agency. (2) Planning services for children with special needs is still not going well, especially in planning specific programs for children with special needs. (3) Services for children with special needs cannot work effectively due to the lack of knowledge of shadow teacher (GPK) non special education about children with special needs. (4) The Lumajang District Education Office has sought training for special non special education guidance teachers about inclusive programs and services for children with special needs.
\end{abstract}

Keywords : Shadow Teacher, Inclusion Schools, Children with Special Needs.

\title{
PENDAHULUAN
}

Pendidikan inklusif bukanlah sebuah topik baru untuk dibahas dalam dunia pendidikan di Indonesia. Pendidikan inklusif di Indonesia sedang berkembang dan selalu dalam pembaharuan untuk memberikan pelayanan yang lebih baik bagi peserta didiknya. Pendidikan inklusif merupakan suatu pendidikan yang menempatkan pemenuhan hak anak untuk memperoleh pendidikan yang sama pada semua anak, baik regular maupun anak berkebutuhan khusus yang sesuai dengan kebutuhannya. Hampir setiap sekolah ingin memberikan peluang bagi anak berkebutuhan khusus untuk dapat belajar bersama dengan anak regular dalam suatu lingkungan sekolah yang inklusif.

Kustawan (2012:7) berpendapat pendidikan inklusif ialah sistem pendidikan yang terbuka bagi semua anak serta mengakomodasikan kebutuhannya sesuai dengan kondisi yang dimiliki oleh anak. Hal ini telah diatur dalam Peraturan Menteri Pendidikan Nasional Nomor 70 Tahun 2009 tentang 
pendidikan inklusif bagi peserta didik yang memiliki kelainan dan memiliki potensi kecerdasan dan/ atau bakat istimewa. Pendidikan inklusif di Jawa Timur telah diatur dalam Peraturan Gubernur Nomor 6 Tahun 2011 tentang penyelenggaraan pendidikan inklusif Provinsi Jawa Timur. Sesuai dengan pedoman teknis penyelenggaraan pendidikan inklusif di Jawa Timur (2014), ruang lingkup pendidikan inklusif apabila ditinjau dari penyelenggaraan pendidikan inklusif menyangkut beberapa hal yaitu lingkungan sekolah yang ramah terhadap peserta didik berkebutuhan khusus, terdapat modifikasi kurikulum, Program Pembelajaran Individual (PPI), identifikasi, asesmen, ruang sumber, guru pembimbing khusus (GPK), pembinaan, pengawasan, monitoring dan evaluasi pendidikan inklusif.

Kabupaten Lumajang merupakan salah satu kabupaten yang berada di Jawa Timur. Kabupaten Lumajang telah menyelenggarakan pendidikan inklusif secara resmi pada tahun 2017. Hal ini diperkuat dengan dikeluarkannya Peraturan Daerah Kabupaten Lumajang Nomor 6 Tahun 2017 tentang Perubahan Atas Peraturan Daerah Nomor 5 Tahun 2015 tengang Penyelenggaraan Pendidikan. Tujuan terselenggaranya sekolah inklusif di Lumajang yaitu untuk memberikan kesempatan yang seluas-luasnya bagi semua anak yang memiliki kelainan fisik, emosional, mental dan sosial atau potensi kecerdasan dan/atau bakat istimewa untuk mendapatkan pelayanan pendidikan yang sesuai dengan kebutuhannya, serta mewujudkan pendidikan yang anti diskriminatif. Oleh karena itu, apabila dipantau dari tujuan dan harapan pemerintah, seyogyanya memberikan pelayanan yang tentunya dapat memenuhi kebutuhan anak berkebutuhan khusus.

Apabila dilihat dari penyelenggaraannya, terdapat 23 sekolah inklusif di kabupaten Lumajang yang terdiri dari jenjang pendidikan dasar yaitu SD dan SMP. Dari 23 sekolah inklusif tersebut terdapat 14 sekolah inklusif yang masih aktif dalam penyelenggaraan pendidikan inklusif (masih memiliki peserta didik anak berkebutuhan khusus). Sekolah ini ditunjuk oleh pemerintah untuk memberikan kesempatan bagi anak berkebutuhan khusus mendapatkan pelayanan pendidikan yang sesuai dengan kebutuhannya. Sekolah wajib mewujudkan suatu pelayanan yang optimal bagi perserta didiknya baik regular maupun berkebutuhan khusus. Guru pembimbing khusus merupakan salah satu penanggung jawab dan memiliki peran penting dalam memenuhi kebutuhan anak berkebutuhan khusus di sekolah inklusif.

Terdapat beberapa tugas bagi guru pembimbing khusus diantaranya, menyelenggarakan administrasi, asesmen, menyusun Program Pendidikan Inklusi, pengadaan dan pengelolaan alat bantu ajar, pembinaan anak berkebutuhan khusus, memodifikasi kurikulum, konseling keluarga, pengembangan pendidikan inklusif, dan menjalin hubungan dengan pihak-pihak pelaksanaan pendidikan inklusif (Rudiyati, 2005:25). Hal ini juga tercantum dalam PP 17 tahun 2010 Pasal (j) menjelaskan bahwa guru pembimbing khusus sebagai pendidik pofesional memiliki tugas dan fungsi 
membimbing, mengajar, menilai, dan mengevaluasi peserta didik berkelainan pada satuan pendidikan umum, satuan pendidikan kejuruan, dan/atau satuan pendidikan keagamaan. Tugas dan tanggung jawab tersebut adalah, merencang dan melaksanakan program kekhususan, melakukan proses identifikasi, asesmen dan menyusun PPI, melakukan modifikasi kurikulum bersama guru kelas atau guru mata pelajaran, melakukan evaluasi dan tindak lanjut, membuat program dan perkembangan peserta didik berkebutuhan khusus. Tugas-tugas inilah yang perlu dilaksanakan oleh guru pembimbing khusus untuk memberikan suatu pelayanan yang optimal bagi peserta didiknya di sekolah inklusif.

Pada saat studi pendahuluan di beberapa sekolah inklusif di Lumajang nampak anak berkebutuhan khusus dengan spesifikasi tunarungu, tunagrahita, tunadaksa dan autis mengalami kesulitan baik dalam proses belajar mengajar maupun dalam kegiatan sehari-harinya di sekolah. Diketahui ketika anak autis mulai memunculkan perilaku yang tidak diinginkan misalnya, memukul temannya, berteriak, tiba-tiba keluar kelas, berlari dan tidak dapat dikendalikan. Guru Pembimbing Khusus menganggapnya sebagai perilaku anak yang nakal. guru pembimbing khusus hanya berusaha memanggilnya ketika ia berlari dan membawanya kembali ke kelas untuk belajar tanpa ada sikap dan perlakuan lainnya yang diambil untuk mereduksi perilaku anak tersebut. Hal ini juga terjadi pada anak yang mengalami gangguan pendengaran atau tunarungu. Mereka masih kesulitan dalam berbahasa, baik dalam mengucapkannya maupun dalam memahami percakapan orang lain. Nampak sosialisasi antara anak berkebutuhan khusus dan regular masih terbatas. Anak berkebutuhan khusus hanya bergaul dengan mereka yang berkebutuhan khusus. Sehingga mempengaruhi anak dalam belajar dan bersosialisasi dengan teman regular. Peran guru pembimbing khusus disini sangat diperlukan untuk memberikan pelayanan yang optimal bagi peserta didiknya yang berkebutuhan khusus, agar mereka dapat mengikuti proses belajar di sekolah inklusif dengan baik dan dapat mengembangkan potensi yang mereka miliki.

Hampir semua sekolah jenjang pendidikan dasar di Lumajang Guru Pembimbing Khusus (GPK) merupakan lulusan non-Pendidikan Luar Biasa (PLB). Hal ini memang bukanlah hal yang dilarang dalam teknis penyelenggaraan pendidikan inklusif. Sesuai dengan pedoman penyelenggaraan inklusif, kriteria Guru Pembimbing Khusus (GPK) berlatar belakang pendidikan luar biasa atau Guru Kelas/Guru Mata Pelajaran yang mendapatkan tugas tambahan sebagai Guru Pembimbing Khusus (GPK). Namun, seberapa optimalkah pelayanan yang diberikan oleh Guru Pembimbing Khusus terhadap anak berkebutuhan khusus di sekolah inklusif tersebut yang menjadi sebuah pertanyaan bagi masyarakat. Beberapa pendapat menyatakan mengenai kredibilitas Guru Pembimbing Khusus yang sering menjadi sorotan. 
Dalam penelitian Rahmaniar (2016) menyatakan bahwa bentuk pelayanan dalam sekolah inklusif berbeda-beda tergantung kebijakan yang diberikan sekolah. Dalam penelitannya di SDN Giwangan Yogyakarta, terdapat Guru Pembimbing Khusus yang telah memberikan pelayanan sesuai dengan kondisi anak dan melaksanakan tugas-tugas sebagai Guru Pembimbing Khusus, serta mengikuti pelatihan, diklat atau seminar untuk mengembangkan program inklusif, bagi guru pembimbing khusus non-PLB masih membutuhkan bimbingan terkait dengan layanan untuk anak berkebutuhan khusus. Sedangkan menurut Kustawan (2013:124) menyatakan bahwa sekolah seharusnya mampu menghadirkan Guru Pembimbing Khusus dari lulusan Pendidikan Luar Biasa dengan harapan mampu memberikan pelayanan yang optimal dalam melayani anak berkebutuhan khusus di sekolah inklusif.

Adanya sekolah inklusif bukanlah sekedar ajang eksistensi sebuah sekolah di suatu daerah. Tanggung jawab besar ditanggung oleh sekolah inklusif untuk memberikan pelayanan yang optimal bagi peserta didiknya terutama anak berkebutuhan khusus. Melalui hal tersebut peneliti ingin menelusuri lebih lanjut bagaimana peranan guru pembimbing khusus non-Pendidikan Luar Biasa (PLB) terhadap pelayanan anak berkebutuhan khusus di Kabupaten Lumajang.

\section{METODE}

Penelitian ini menggunakan pendekatan penelitian kualitatif dengan jenis penelitian dekskriptif kualitatif. Pendekatan ini dipilih karena berkenaan dengan mengungkapkan kejadian secara mendalam dan terfokus pada kejadian yang ditemukan secara alami. Hal ini sesuai dengan pernyataan Sugiono (2016:15) penelitian kualitatif adalah meneliti suatu kondisi obyek yang alamiah dimana peneliti sebagai instrumen. Fokus penelitian ini yaitu mendeskripsikan pengaruh Guru Pembimbing Khusus lulusan non-PLB terhadap pelayanan yang diberikan untuk anak berkebutuhan khusus di Kabupaten Lumajang. Dalam penelitian ini menggunakan rancangan penelitian deskripsi self-report. Menurut Sukardi (2016:159) rancangan penelitian dengan bentuk laporan sendiri (self-report) merupakan rancangan penelitian yang informasinya dikumpulkan langsung oleh peneliti.

Penelitian ini dilaksanakan di tiga sekolah inklusif di Kabupaten Lumajang yakni, SDN Kutorenon 02, SMPN PGRI Sukodono, dan SMP Ibnu Sina Lumajang. Penelitian ini menggunakan teknik pengumpulan data observasi, wawancara, dan dokumentasi.

Observasi yang diterapkan adalah observasi terbuka. Observasi dilaksanakan di lingkungan sekolah inklusif yang dituju baik di dalam kelas maupun di luar di luar kelas. Kelas yang menjadi sasaran dalam sekolah tersebut adalah kelas yang terdapat anak berkebutuhan khusus. Kegiatan observasi berlangsung pada saat proses belajar mengajar, dengan melihat bagaimana peran guru 
pembimbing khusus dalam melayani anak berkebutuhan khusus dan aktivitas anak di luar kelas seperti pada saat beristirahat atau bermain dengan teman-temannya (kegiatan sosialisasi), mengikuti kegiatan ekstrakurikuler, dan lain-lain. Melihat sejauh mana guru pembimbing khusus melaksanakan program yang telah direncanakan serta problematika yang dihadapi pada saat memberikan pelayanan pada anak berkebutuhan khusus.

Wawancara yang digunakan dalam penelitian ini adalah wawancara terstruktur. Wawancara terstruktur adalah teknik wawancara dimana peneliti bertatap muka dengan responden dengan menggunakan pedoman yang telah dipersiapkan sebelumnya (Sukardi, 2014:80). Wawancara digunakan untuk memperoleh data terkait perencanaan guru pembimbing khusus dalam membimbing anak berkebutuhan khusus di sekolah inklusif, pelaksanaan program yang telah disusun oleh guru pembimbing khusus, hambatan yang dialami oleh guru pembimbing khusus dalam memberikan layanan pada anak berkebutuhan khusus di sekolah inklusif serta solusi guru pembimbing khusus dalam menghadapi problematika pelayanan di sekolah inklusif. Responden dalam wawancara meliputi kepala sekolah, guru pembimbing khusus, koordinator bagian sekolah inklusif Dinas Pendidikan Kabupaten Lumajang.

Dokumentasi dalam penelitian ini digunakan untuk memberikan informasi baru, memperjelas dan memperkuat informasi yang telah diperoleh melalui observasi dan wawancara. Data yang ditelusuri dalam dokumentasi adalah data kepala sekolah, guru pembimbing khusus, perencanaan program pembelajaran atau penanganan bagi anak berkebutuhan khusus, data perkembangan anak berkebutuhan khusus sebelum dan selama belajar di sekolah tersebut.

Data penelitian yang telah didapat melalui observasi, wawancara dan dokumentasi dianalisis dengan menggunakan model analisis Miles, Huberman, \& Saldana (2014:30-32) yaitu kondensasi data, penyajian data dan penarikan kesimpulan dan verifikasi.

\section{HASIL DAN PEMBAHASAN}

Hasil penelitian meliputi perencanaan, pelaksanaan pelayanan guru pembimbing khusus di sekolah inklusif kabupaten Lumajang yang terdiri dari identifikasi, asesmen, program pembelajaran individu, program kekhususan dan modifikasi kurikulum, problematika guru pembimbing khusus dalam memberikan layanan di sekolah inklusif kabupaten Lumajang, dan solusi yang diambil dalam mengatasi problematika pelayanan di sekolah inklusif kabupaten Lumajang.

Dalam penelitian ini seluruh sekolah memiliki guru pembimbing khusus yang ditugaskan langsung atau ditunjuk untuk melaksanakan tugasnya sebagai guru pembimbing khusus. Guru pembimbing khusus berasal dari guru kelas atau guru mata pelajaran yang notabenenya bukan dari 
lulusan Pendidikan Luar Biasa. Maka data hasil penelitian ini dideskripsikan dengan data sebagai berikut:

\section{Perencanaan Guru Pembimbing Khusus Dalam Pelayanan Anak Berkebutuhan Khusus di} Sekolah Inklusif Kabupaten Lumajang

Peranan Guru Pembimbing khusus dalam memberikan sebuah pelayanan diperlukan sebuah perencanaan. Dalam lingkup sekolah inklusif guru pembimbing khusus bertugas merencanakan identifikasi, asesmen, PPI, program kekhususan dan modifikasi kurikulum. Berdasarkan hasil penelitian guru pembimbing khusus di SDN Kutorenon 2, SMP Ibnu Sina dan SMP PGRI Sukodono belum membuat perencanaan tentang program kekhususan untuk peserta didik berkebutuhan khusus. Hal ini dikarenakan pengetahuan mengenai anak berkebutuhan khusus sangat kurang, mereka tidak mengerti mengenai program-program khusus untuk peserta didiknya yang terdiri dari tunarungu, tunawicara, tunagrahita, tunadaksa dan lambat belajar.

Perencanaan identifikasi, asesmen, dan PPI di SMPN PGRI Sukodono dan SMP Ibnu Sina masih belum diterapkan secara administratif. Sedangkan di SDN Kutorenon 2 sudah melaksanakan perencanaan asesmen untuk peserta didik berkebutuhan khusus.

\section{Pelaksanaan Pelayanan Guru Pembimbing Khusus di Sekolah Inklusif Kabupaten Lumajang}

Pelaksanaan ini terdiri dari identifikasi, asesmen, program pembelajaran individu, modifikasi kurikulum, serta pelayanan khusus yang sesuai dengan kebutuhan peserta didik berkebutuhan khusus. Secara keseluruhan identifikasi telah dilaksanakan pada semua sekolah, namun mereka tidak memiliki laporan tertulis mengenai hasil identifikasinya. Tidak semua sekolah melakukan asesmen untuk anak berkebutuhan khusus. Pada SMP PGRI Sukodono misalnya, guru pembimbing khusus tidak memahami tentang makna asesmen, fungsi dan isi dari asesmen. Di SMP Ibnu Sina guru pembimbing khusus juga tidak melaksanakan asesmen karena memiliki pemahaman yang kurang tentang asesmen. Berbeda dengan SDN Kutorenon 2, guru pembimbing khusus SDN Kutorenon 2 melaksanakan asesmen namun tidak pada awal peserta didik masuk di sekolah tersebut. Teknik dalam mengasesmen serta isi dalam asesmen masih belum terlalu mendalam untuk mengetahui informasi kondisi anak berkebutuhan khusus. Teknik yang digunakan dalam mengasesmen adalah tes tertulis.

Program pembelajaran individu (PPI) merupakan komponen penting bagi anak berkebutuhan khusus, melalui PPI anak berkebutuhan khusus dapat belajar secara individu sesuai dengan kemampuan yang ia miliki agar dapat berkembang dengan baik. Secara administratif semua sekolah tidak membuat program pembelajaran individu untuk anak berkebutuhan khusus. Mereka 
hanya belajar pada situasi kelas yang sama. Ditinjau dari hasil penelitian, SDN Kutorenon 2 telah menerapkan program pembelajaran individu yang bertujuan untuk mengembangkan kemampuan motorik, serta kemampuan berbahasa. Namun, dalam pelaksanaannya masih kurang karena fasilitas yang dimiliki seperti ruang sumber, media dan tenaga pendidik yang kurang mengetahui teknik pengajaran untuk anak berkebutuhan khusus.

Modifikasi kurikulum telah dilakukan di sekolah inklusif yang diteliti. Beberapa sekolah seperti SMP Ibnu Sina, dan SMP PGRI Sukodono melakukan modifikasi kurikulum yang disesuaikan dengan kemampuan anak berkebutuhan khusus. Modifikasi kurikulum yang dilakukan guru pembimbing khusus tidak tertulis secara administratif. Guru pembimbing khusus langsung pada tahap pelaksanannya saja tanpa perencanaan, tanpa melihat sejauh mana anak dapat memahami sebuah materi pelajaran sehingga materi yang diberikan terkadang tidak sesuai dengan kebutuhannya. Sedangkan di SDN Kutorenon 2 pembelajaran berjalan sesuai dengan kurikulum yang ada. Jadi untuk anak berkebutuhan khusus dan anak regular memiliki bobot pelajaran dan soal yang sama. Hal ini memberikan dampak dalam proses belajar anak. Terlihat banyak siswa yang merasa kesulitan, mereka mengerjakannya dengan cukup lambat dibandingkan dengan anak regular. Guru pembimbing khusus membantu siswa yang terlihat kesulitan, namun tidak semua anak bisa teratasi karena dalam satu kelas terlalu banyak membuat anak berkebutuhan khusus sedangkan hanya ada satu guru pembimbing khusus. Guru pembimbing khusus yang berada di kelas tersebut sekaligus sebagai guru kelas di kelas, sehingga tugasnya tidak hanya mengakomodasi anak-anak berkebutuhan khusus, melainkan juga anak regular. Terlihat pembelajaran nampak kurang efektif.

Guru pembimbing khusus dalam sekolah inklusif merupakan tugas tambahan yang diberikan pada guru kelas atau guru mata pelajaran yang ditunjuk. Dalam memberikan pelayanan pada anak berkebutuhan khusus, guru pembimbing khusus terlihat optimal dalam melayani ketika ia masuk kelas dan memberikan pelajaran yang sesuai dengan bidangnya (tugas utama guru pembimbing khusus sebagai pengajar mata pelajaran). Sedangkan, ketika guru pembimbing khusus tidak melakukan tugas utamanya (mengajar mata pelajaran) pendampingan sangat jarang dilakukan. Namun, dari beberapa sekolah guru regular juga dihimbau untuk saling membantu anak berkebutuhan khusus dalam belajarnya dan sebisa mungkin tidak terlalu memaksakan kemampuan anak berkebutuhan khusus di dalam kelas.

Melalui hasil penelitian diketahui program khusus tidak dapat berjerla karena tidak adanya perencanaan dari guru pembimbing khusus. Hal ini dikarenakan pemahaman guru pembimbing khusus yang masih kurang terhadap pelayanan yang berkaitan dengan program khusus. 


\section{Problematika Guru Pembimbing Khusus dalam Pemberian Layanan di Sekolah Inklusif} Kabupaten Lumajang

Melalui hasil penelitian terdapat beberapa problematika yang dialami oleh guru pembimbing khusus dalam memberikan pelayanan untuk peserta didik berkebutuhan khusus. Secara administratif, guru pembimbing khusus tidak melakukan pelayanan secara optimal seperti dalam proses identifikasi, asesmen, PPI, modifikasi perilaku dan program khusus. Guru pembimbing khusus yang berada di sekolah inklusif berasal dari guru kelas/guru mata pelajaran yang notabenenya lulusan non-PLB sehingga pengetahuan guru pembimbing khusus tentang anak berkebutuhan khusus dan pemahaman tentang konsep sekolah inklusif cukup terbatas. Hal ini mengakibatkan guru pembimbing khusus tidak dapat memberikan penanganan lebih untuk menangani anak berkebutuhan khusus di sekolah inklusif.

SDN Kutorenon 2 memiliki 15 anak berkebutuhan khusus yang terdiri dari jenis ketunaan tunarungu, tunagrahita, autis dan lambat belajar. SMPN PGRI Sukodono memiliki 5 anak berkebutuhan khusus yang terdiri dari jenis ketunaan tunawicara, tunagrahita dan lambat belajar. SMP Ibnu Sina memilik 4 anak berkebutuhan khusus yang terdiri dari jenis ketunaan tunagrahita, tunadaksa dan autis.

Beberapa dari guru pembimbing khusus mengeluhkan bahwa sebenarnya mereka tidak memiliki banyak pengetahuan tentang anak berkebutuhan khusus, sehinga mereka merasa kesulitan dalam menghadapi dan memberikan pelayanan pada anak berkebutuhan khusus. Apalagi untuk menangani anak tunarungu, tunawicara dan autis yang memiliki hambatan dalam berkomunikasi. Fasilitas yang masih kurang mendukung dalam proses pelayanan anak berkebutuhan khusus, menjadi salah satu penghambat program yang direncanakan sehingga belum dapat berjalan dengan maksimal, khususnya SDN Kutorenon 2 yang telah memiliki program bagi peserta didik berkebutuhan khusus.

\section{Solusi Guru Pembimbing Khusus yang Diambil dalam Mengatasi Problematika Pelayanan}

\section{di Sekolah Inklusif Kabupaten Lumajang.}

Melalui beberapa permasalahan yang dialami oleh guru pembimbing khusus di sekolah, tentunya guru pembimbing khusus tidak hanya sekedar diam atau tidak mengupayakan solusi untuk peserta didiknya. Meskipun dengan keterbatasan ilmu yang mereka miliki, mereka berupaya untuk tetap memperhatikan anak berkebutuhan khusus dalam pelajaran. Seperti yang dilakukan di SMPN PGRI Sukodono, ketika anak berkebutuhan khusus dalam proses belajar di kelas, guru pembimbing khusus menjelaskan materi kepada anak di kelas, guru pembimbing khusus tidak lupa untuk mengajak anak untuk berinteraksi semampunya. Latihan soal yang diberikan untuk anak 
berbeda dengan anak regular, dikarenakan ia tidak mampu menulis dan membaca sehinga soal yang diberikan berbentuk latihan menulis huruf. Anak berkebutuhan khusus di SMPN PGRI Sukonodo memiliki spesifikasi tunawicara, tunagrahita, dan lambat belajar. Beberapa aktivitas diatas juga diterapkan di SMP Ibnu Sina, yang dimana anak berkebutuhan khusus di SMP Ibnu Sina adalah autis, tunagrahita, tunadaksa dan lambat belajar. Sedangkan di SDN Kutorenon 2, guru pembimbing khusus berusaha mendampingi anak untuk memahami dengan kurikulum yang sama dengan anak regular.

Sebuah problema yang dihadapi oleh guru pembimbing khusus di sekolah inklusif ternyata dinas pendidikan setempat tidak tinggal diam. Dinas pendidikan kabupaten Lumajang ikut membantu untuk memberikan solusi terhadap permasalahan yang dialami oleh sekolah-sekolah inklusif yang ada di kabupaten Lumajang. Dinas pendidikan mengetahui adanya guru pembimbing khusus yang memang notabenenya adalah lulusan non-PLB sehingga dinas pendidikan mengadakan sebuah workshop atau seminar mengenai program pendidikan inklusif dan kebutuhan anak berkebutuhan khusus di sekolah inklusif. Menurut hasil penelitian, dinas pendidikan terkait mengalokasikan sebagian besar dana inklusi untuk melaksanakan workshop selama dua hari yang dihadiri oleh perwakilan kepala sekolah dan dua guru dari sekolah inklusif yang ada di kabupaten Lumajang. Dua guru tersebut terdiri dari satu guru matapelajaran atau guru kelas, dan satu GURU PEMBIMBING KHUSUS yang ditugaskan oleh sekolah.

\section{Pembahasan}

Sesuai dengan pedoman penyelenggara pendidikan inklusif (2007) guru pembimbing khusus merupakan guru yang memiliki latar belakang pendidikan khusus atau luar biasa atau yang pernah mendapat pelatihan tentang pendidikan khusus/luar biasa yang ditugaskan di sekolah inklusif. Keberadaan guru pembimbing khusus sangat diperlukan untuk mendidik anak berkebutuhan khusus di sekolah inklusif. Sesuai dengan hasil penelitian didapatkan tugas-tugas guru pembimbing khusus yang berkaitan dengan bentuk pelayanan bagi anak berkebutuhan khusus di sekolah inklusif. Menurut PP 17 tahun 2010 Pasal (j) menjelaskan bahwa guru pembimbing khusus sebagai pendidik pofesional memiliki tugas dan fungsi membimbing, mengajar, menilai, dan mengevaluasi peserta didik berkelainan pada satuan pendidikan umum, satuan pendidikan kejuruan, dan/atau satuan pendidikan keagamaan. Apabila dijabarkan lebih lanjut tugas guru pembimbing khusus diantaranya sebagai berikut, merancang dan melaksanakan program kekhususan, melakukan proses identifikasi, asesmen dan menyusun PPI, melakukan modifikasi kurikulum bersama guru kelas atau guru mata pelajaran, membangun sistem koordiasi antara guru, pihak sekolah dan orang tua peserta didik, melaksanakan 
pendampingan anak berkebutuhan khusus pada kegiatan pembelajaran bersama-sama dengan guru kelas/guru mata pelajaran, memberikan bantuan layanan khusus bagi anak berkebutuhan khusus yang mengalami hambatan dalam mengikuti kegiatan pelajaran di kelas umum, berupa remidi atau pengayaan, memberikan bimbingan secara berkesinambungan dan membuat catatan khusus kepada anak berkebutuhan khusus selama mengikuti kegiatan pelajaran, yang dapat dipahami jika terjadi pergantian guru, memberikan bantuan pada guru kelas dan/atau guru mata pelajaran agar mereka juga dapat memberikan pelayanan bagi anak berkebutuhan khusus. melakukan evaluasi dan tindak lanjut, membuat program dan perkembangan peserta didik berkebutuhan khusus (Pedoman Khusus Penyelenggara Inklusi Tahun 2007).

Sesuai dengan temuan yang didapatkan dalam hasil penelitian, semua sekolah yang diteliti memiliki guru pembimbing khusus yang ditunjuk langsung oleh sekolah untuk melaksanakan tugas tambahan sebagai guru pembimbing khusus. Sehingga guru pembimbing khusus di sekolah tersebut adalah guru mata pelajaran atau guru kelas yang notabenenya bukanlah lulusan Pendidikan Luar Biasa, melainkan lulusan PGSD, pendidikan Bahasa Indonesia, Pendidikan Matematika, Pendidikan Sains, Pendidikan Olahraga.

Ditinjau dari tugas dan fungsi guru pembimbing khusus di sekolah inklusif rata-rata mereka masih belum melaksanakannya dengan baik sehingga mempengaruhi pelayanan bagi anak berkebutuhan khusus yang berada di sekolah inklusif. Kemampuan guru pembimbing khusus dalam memahami peserta didik berkebutuhan khusus masih kurang, masih diperlukan lagi pendalaman pengetahuan mengenai anak berkebutuhan khusus dan program inklusif di sekolah. Peranan guru pembimbing khusus tidak dapat digantikan dengan oleh guru lain karena perannya berbeda dibandingkan dengan guru mata pelajaran atau guru kelas (Zakia, 2015).

Ditinjau melalui perencanaan program bagi anak berkebutuhan khusus di sekolah inklusif yang telah diteliti hanya SDN Kutorenon 2 yang memiliki perencanaan program dengan tujuan memberikan pelayanan kekhususan bagi peserta didik berkebutuhan khusus. Namun, SDN Kutorenon 2 dalam merencanakan program kurang terstruktur dikarenakan secara administratif masih belum dilaksanakan. Hal ini nampak kurang sempurna karena perkembangan anak berkebutuhan khusus akan kurang terlihat karena tidak ada catatan khusus bagi mereka, sehingga tidak diketahui apakah program tersebut layak untuk terus diterapkan bagi anak berkebutuhan khusus atau perlu untuk diperbaiki lagi. Hal ini berkaitan dengan evaluasi program bagi anak berkebutuhan khusus. Menurut Kustawan (2012) evaluasi merupakan suatu proses sistematis dalam mengumpulkan, menganalisis dan menginterpretasikan informasi untuk mengetahui seberapa besar tingkat keberhasilan pelaksanaan suatu program yang telah diterapkan untuk peserta didik berkebutuhan khusus dengan kriteria tertentu yang telah ditetapkan untuk pengambilan suatu keputusan. 
Guru pembimbing khusus di sekolah inklusif telah melaksanakan identifikasi pada semua anak berkebutuhan khusus ketika awal anak masuk di sekolah inklusif. Namun, beberapa sekolah seperti SMPN PGRI Sukodono dan SMP Ibnu Sina masih belum melaksanakan asesmen untuk mengetahui seberapa besar tingkat kemampuan dan kelemahan anak dalam proses belajar maupun dalam bidang yang dimiliki. Asesmen di SDN Kutorenon 2 menggunakan instrumen perkembangan usia. Menurut Rahmaniar (2016) instrumen perkembangan usia berguna untuk mengetahui usia mental siswa sebagai acuan program pembelajaran yang akan diberikan. Asesmen merupakan suatu proses untuk mendapatkan informasi dalam bentuk apapun yang dapat digunakan sebagai dasar pengambilan keputusan tentang peserta didik (Triani, 2012:5). Jadi dapat disimpulkan bahwa sangat penting sekali identifikasi dan asesmen untuk dilakukan pada anak berkebutuhan khusus di sekolah inklusif.

Program pembelajaran individual merupakan suatu hal yang penting untuk diterapkan sebagai bentuk pelayanan anak berkebutuhan khusus di sekolah inklusif. Dengan adanya PPI kita dapat mengetahui tentang level kemampuan dan perkembangan siswa, memuat tujuan jangka panjang dan jagka pendek untuk anak yang diterapkan melalui suatu program kekhususan (Eileen\&Gylnnis, 2012:267).

Pelaksanaan modifikasi kurikulum di sekolah inklusif sudah terlaksana meskipun dalam pelaksanaannya masih belum diterapkan secara administratif. Jadi pelaksanaannya langsung tanpa perencanaan tertulis melainkan spontan ketika guru pembimbing khusus memberikan pelajaran sesuai dengan jadwal anak berkebutuhan khusus. Namun, yang sering terjadi adalah guru mata pelajaran atau guru kelas memberikan soal sesuai dengan kemampuan anak tanpa pendampingan guru pembimbing khusus, seperti yang dilakukan di SMP Ibnu Sina dan SMPN PGRI Sukodono. Apabila ditinjau dari model modifikasi kurikulum, ke dua sekolah tersebut menggunakan model kurikulum omisi, dimana pada suatu mata pelajaran peserta didik berkebutuhan khusus menggunakan kurikulum di bawah standart. Beberapa bagian dari kurikulum standart ditiadakan sama sekali karena anak berkebutuhan khusus yang tidak memungkinkan untuk dicapai oleh peserta didik berkebutuhan khsusus (Pedoman Teknis Penyelenggaraan Inklusif, 2014). Sedangkan di SDN Kutorenon 2 peserta didik berkebutuhan khusus menggunakan model kurikulum umum (duplikasi). Pada model kurikulum ini, peserta didik berkebutuhan khusus mengikuti kurikulum standart satuan pendidikan seperti pada anak regular. Seharusnya dalam pembuatan modifikasi kurikulum dilakukan melalui kerjasama antara guru pembimbing khusus dan guru kelas/guru) mata pelajaran (Pedoman Teknis Penyelenggaraan Inklusif, 2014).

Beberapa hal yang telah dijabarkan melalui hasil penelitian merupakan tugas seorang guru pembimbing khusus yang sekaligus sebagai bentuk layanan seorang guru pembimbing khusus disuatu lingkung sekolah inklusif yang ditujukan untuk peserta didik berkebutuhan khusus. Dengan 
melakukan tugasnya seperti, perencanaan program kekhususan, identifikasi, asesmen, pembuatan PPI dan modifikasi kurikulum merupakan bentuk guru pembimbing khusus memberikan layanan untuk anak berkebutuhan khusus yang sesuai dengan kebutuhannya.

Problematika yang dihadapi oleh guru pembimbing khusus di sekolah inklusif Lumajang antara satu guru pembimbing khusus dengan guru pembimbing khusus lainnya hampir serupa. Mereka mengakui bahwa pelayanan yang mereka berikan memang kurang untuk peserta didik berkebutuhan khusus. Dilihat melalui hasil penelitian, hal ini terjadi dikarenakan pengetahuan, pelayanan dan program inklusif bagi anak berkebutuhan khusus masih sangat terbatas.

Dinas Pendidikan Lumajang telah mengetahui bahwa guru pembimbing khusus yang berada pada sekolah inklusif tersebut berasal dari guru kelas atau guru mata pelajaran yang ditunjuk untuk mendapatkan tugas tambahan sebagai guru pembimbing khusus. Hal ini tentunya tidak bertentangan dengan pelaksanaan inklusif. Menurut pedoman teknis pelaksanaan pendidikan inklusif di Jawa Timur (2014), kriteria guru pembimbing khusus berasal dari latar belakang pendidikan luar biasa atau guru berasal dari guru kelas/guru mata pelajaran yang mendapatkan tugas tambahan sebagai guru pemebimbing khusus. guru pembimbing khusus yang berasal dari guru kelas atau guru mata pelajaran mendapat beban tambahan mengajar paling sedikit enam jam tatap muka dalam satu minggu di ruang sumber dan mendapatkan pendidikan/pelatihan sebagai guru pembimbing khusus minimal 80 jam pelatihan dengan materi yang sesuai dengan kompetensi dan tugas guru pembimbing khusus.

Dinas Pendidikan Lumajang telah mengupayakan untuk melakukan peningkatan kualitas guru pembimbing khusus yang berasal dari non-PLB melalui kegiatan pelatihan yang dilaksanakan oleh Dinas Pendidikan berupa workshop. Menurut hasil penelitian, workshop yang dilaksanakan untuk meningkatkan kompetensi guru terhadap pelayanan anak berkebutuhan khusus di sekolah inklusif diwakili oleh kepala sekolah, satu guru kelas atau guru mata pelajaran dan satu guru pembimbing khusus. Pelaksanaan workshop selama satu kali dalam satu tahun, dengan waktu pelatihan yang diikuti kurang dari 80 jam atau hanya dua hari. Tentunya pengetahuan mengenai anak berkebutuhan khusus dan bentuk pelayanan serta program inklusif masih kurang.

Pendidikan inklusif di Lumajang dapat dikatakan baru atau masih merintis karena pelaksanaan pendidikan inklusif di Lumajang dimulai pada tahun 2017. Sehingga masih wajar apabila banyak sekali kekurangan dalam pelaksanaannya terutama pada pelayanan bagi anak berkebutuhan khusus di sekolah inklusif, khususnya pelayanan guru pembimbing khusus terhadap peserta didik berkebutuhan khusus. guru pembimbing khusus wajib memberikan layanan-layanan khusus untuk mengoptimalkan segala potensi dan mereduksi perilaku yang tidak diinginkan dari diri anak berkebutuhan khusus. guru pembimbing khusus perlu menjalankan perencanaan program dan pelaksanaan identifikasi, asesmen, pembuatan PPI dan modifikasi perilaku serta program-program 
lain yang dibutuhkan oleh anak dalam sekolah inklusif. Melalui pernyataan tersebut tugas guru pembimbing khusus tidak dapat digantikan dengan guru lainnya, karena tugas antara guru pembimbing khusus dan guru kelas maupun guru mata pelajaran sangat berbeda.

Guru pembimbing khusus yang berasal dari lulusan non-PLB memiliki potensi yang baik untuk memberikan pelayanan pada anak berkebutuhan khusus di sekolah inklusif. Sesuai dengan hasil penelitian secara tidak langusng mereka memberikan suatu pelayanan dengan cara autodidak. guru pembimbing khusus yang berada di sekolah inklusif sebenarnya telah melakukan beberapa tugasnya, namun tidak terencana dengan baik, baik secara administrasi maupun perencanaannya. Agar dapat memberikan pelayanan yang terbaik, guru pembimbing khusus non-PLB membutuhkan bimbingan terkait layanan peserta didik berkebutuhan khusus. Peranan pemerintah dibutuhkan untuk mengadakan pelatihan untuk menyiapkan guru pembimbing khusus yang berkualitas baik. Sehingga mobilitas seorang guru pembimbing khusus lebih siap dan tahu arah mengenai pelayanan yang akan diberikan untuk anak berkebutuhan khusus.

Kustawan (2013:124) menyatakan bahwa sekolah inklusif seharusnya mampu menghadirkan Guru Pembimbing Khusus dari lulusan Pendidikan Luar Biasa, dengan harapan mampu memberikan pelayanan yang optimal dalam melayani anak berkebutuhan khusus di sekolah inklusif. Teori ini dapat dikatakan bertentangan dengan hasil penelitian yang telah dilakukan, karena sebenarnya guru pembimbing khusus memiliki potensi yang sama untuk mendidik dan memberikan pelayanan bagi peserta didik berkebutuhan khusus di sekolah inklusif, hanya saja perlu bimbingan lebih lanjut agar dapat melayani anak berkebutuhan khusus secara optimimal dan sesuai dengan kebutuhannya.

\section{PENUTUP}

\section{Simpulan}

Kesimpulan dalam penelitian ini disampaikan sebagai berikut:

1. Guru pembimbing khusus yang ada di sekolah inklusif merupakan guru kelas atau guru mata pelajaran yang ditugaskan sekolah untuk menjadi guru pembeimbing khusus sebagai tugas tambahan. Sehingga, guru pembimbing di sekolah inklusif di kabupaten Lumajang bukanlah lulusan Pendidikan Luar Biasa, melainkan lulusan PGSD, pendidikan Bahasa Indonesia, Pendidikan Matematika, Pendidikan Sains, Pendidikan Olahraga.

2. Perencanaan pelayanan bagi anak berkebutuhan khusus masih belum berjalan dengan baik, terutama dalam perencanaan program kekhususan bagi anak berkebutuhan khusus. Hal ini dikarenakan pengetahuan mengenai anak berkebutuhan khusus sangat kurang, mereka tidak mengerti program-program khusus untuk peserta didiknya yang terdiri dari tunarungu, tunawicara, tunagrahita, tunadaksa dan lambat belajar. 
3. Pelayanan terhadap anak berkebutuhan khusus di sekolah inklusif Lumajang yang ditangani guru pembimbing khusus non-PLB masih belum berjalan dengan optimal. Hal ini dikarenakan pengetahuan guru pembimbing khusus non-PLB tentang anak berkebtuhan khusus, penanganan dan layanan serta program inklusif bagi anak berkebutuhan khusus masih kurang. Selain itu, pendidikan inklusif di Lumajang pelaksanaannya masih terbilang baru, sehingga masih banyak kekurangan dalam pelaksanaannya.

4. Pemerintah telah mengupayakan untuk meningkatkan kemampuan guru pembimbing khusus nonPLB dengan memberikan pelatihan berupa workshop tentang anak berkebutuhan khusus, pelayanan dan kebutuhan anak berkebutuhan khusus serta program inklusif.

\section{Saran}

1. Penyelenggara pendidikan inklusi memiliki kewajiban untuk memahami komponen dalam penyelenggaraannya, terutama dalam hal tenaga kerja yaitu mengenai guru pembimbing khusus.

2. Seorang guru non-PLB yang ditunjuk oleh sekolah menjadi GPK memiliki kewajiban untuk meningkatkan keilmuannya khususnya dalam memahami anak berkebutuhan khusus agar mampu memberikan pelayanan sesuai dengan kewenangannya.

3. Perlu adanya kerjasama antara dinas pendidikan dengan sekolah penyelenggara inklusi agar terjalin suatu hubungan yang baik dalam pengimplementasian pendidikan inklusi, khususnya di kabupaten Lumajang.

\section{DAFTAR PUSTAKA}

Allen, K, Eileen and Cowdery, Gylnnis E. 2012. The Exceptional Child: Inclusion in Early Childhood, Seventh Edition. America: Wadsworth Cengage Learning.

Departemen Pendidikan Nasional. 2009. Peraturan Menteri Pendidikan Nasional Nomor 70 Tahun 2009. Jakarta.

Departemen Pendidikan Nasional. 2007. Pedoman Khusus Penyelenggaraan Pendidikan Inklusif tentang Pengadaan dan Pembinaan Tenaga Pendidik. Jakarta: Direktorat Pembinaan Sekolah Luar Biasa.

Dinas Pendidikan Pemerintah Provinsi Jawa Timur. 2014. Pedoman Teknis Penyelenggaraan Pendidika Inklusif di Jawa Timur. Surabaya: Dinas Pendidikan Provinsi Jawa Timur.

Kustawan, Dedy. 2012. Pendidikan Inklusif \& Upaya Implementasinya. Jakarta: PT. Luxima Metro Media.

Kustawan, Dedy dan Meimulayni, Yani. 2013. Mengenal Pendidikan Khusus dan Pendidikan Layanan Khusus serta Implementasinya. Jakarta Timur: Luxima Metro Media. 
Miles, Metthew B, A, et al. 2014. Qualitative Data Analysis, A Methods Sourcebook. Third Edition. United State of America: Stage Publications, Inc.

Peraturan Daerah Kabupaten Lumajang. 2017. peraturanDaerah Kabupaten Lumajang Nomor 6 Tahun 2017 Tentang Perubahan Atas Peraturan Daerah Nomor 2 Tahun 2015 Tentang Penyelenggaraan Pendidikan. Bupati Lumajang. Lumajang.

Peraturan Gubernur Jawa Timur. 2011. Peraturan Gubernur Jawa Timur Nomor 6 Tahun 2011 Tentang Penyelenggaraan Pendidikan Inklusif Jawa Timur. Gubernur Jawa Timur. Surabaya.

Rahmaniar. 2016. "Tugas Guru Pendamping Khusus (GPK) dalam memberikan Pelayanan Pendidikan Siswa Berkebutuhan Khusus di Sekolah Inklusif SD Negeri Giwangan Yogyakarta". Jurnal Widia Ortodidaktika. Vol. 5 No. 12.

Rudiyati, Sari. 2005. "Peran dan Tugas Guru Pembimbing Khusus "Special/Resource Teacher" dalam Pendidikan Terpadu/Inklusi". Jurnal Pendidikan Khusus, Vo. 1 No. 1, (online), (http://staff.uny.ac.id/sites/default/files/penelitian/Dr.\%20Sari\%20Rudiyati,\%20M.Pd./JPK\% 20No\%201\%20Vol\%201\%20Juni\%2020005.pdf, diunduh 16 November 2018).

Sugiyono. 2016. Metode Penelitian Pendidikan Pendekatan Kuantitatif, Kualitatif, dan $R \& D$. Bandung: Alfabeta.

Sukardi. 2014. Metodologi Penelitian Pendidikan Kompetensi dan Praktiknya. Jakarta: Bumi Aksara.

Triani, Nani. 2012. Panduan Asesmen Anak Berkebutuhan Khusus. Jakarta Timur: Luxima Metro Media.

Zakia, Dieni Laylatul. 2015. Guru Pembimbing Khusus (GPK): Pilar Pendidikan Inklusi. Artikel dipresentasikan di Universitas Sebelas Maret dan ISPI Wilayah Jawa Tengah. Semarang, 21 November. 